\title{
The diversity of 'kristal' guava (Psidium guajava) fruit quality in response to different altitudes and cultural practices
}

\author{
NENI MUSYAROFAH ${ }^{1,2}$, SLAMET SUSANTO ${ }^{3, »}$, SANDRA ARIFIN AZIZ ${ }^{3}$, KETTY SUKETI $^{3}$, DADANG $^{4}$ \\ ${ }^{1}$ Agronomy and Horticulture Program, Graduate School, Institut Pertanian Bogor, Jl. Meranti, Kampus IPB Darmaga, Bogor 16680, West Java, Indonesia \\ ${ }^{2}$ Sustainable Agriculture Extension Program, Politeknik Pembangunan Pertanian Bogor. Jl. Aria Surialaga No 1, Pasir Jaya, Bogor 16119, West Java, \\ Indonesia \\ ${ }^{3}$ Department of Agronomy and Horticulture, Faculty of Agriculture, Institut Pertanian Bogor. Jl. Meranti, Kampus IPB Darmaga, Bogor 16680, West \\ Java, Indonesia. Tel./fax.: +62-251-8629353, ^email: slmtsanto@ gmail.com \\ ${ }^{4}$ Department of Plant Protection, Faculty of Agriculture, Institut Pertanian Bogor. Jl. Kamper, Kampus IPB Darmaga, Bogor 16680-Indonesia.
}

Manuscript received: 16 December 2019. Revision accepted: 26 June 2020.

\begin{abstract}
Musyarofah N, Susanto S, Aziz SA, Suketi K, Dadang. 2020. The diversity of 'kristal' guava (Psidium guajava) fruit quality in response to different altitudes and cultural practices. Biodiversitas 21: 3310-3316. The current study aimed to compare the quality of 'kristal' guava fruit harvested from different altitudes under different cultural practices. The study was conducted from January to March 2019. Four treatments were examined, i.e., fruit from low altitude-intensive cultural (LI), low altitude-less intensive cultural (LI), middle altitude-intensive cultural (MI), and middle altitude-less intensive cultural (ML). All treatments were arranged in a completed randomized design and each treatment had five trees as replicates The findings of the study showed that there was a variation of fruit quality in response to different altitudes and cultural practices. The fruits harvested from low altitudes were significantly bigger and heavier than the fruits harvested from middle altitude, irrespective of cultural practices. With regard to fruit softness, the fruits from middle altitudes were crispier than fruits from the low altitude. The chemical qualities of the fruits, indicated by TSS/TA ratio and vitamin $\mathrm{C}$, were better in guava orchard under intensive cultural practice than less intensive cultural practice. The intensive cultural practice also improved the guava fruit size as compared to the less intensive cultural practice. This finding may be attributed to pruning which is performed in intensive cultural practice. More beneficial metabolites for human health such as vitamin E and caryophyllene were found in fruit from low altitude.
\end{abstract}

Keywords: Caryophyllene, GC-MS, heatmap cluster gram, intensive cultural, low altitude, middle altitude

\section{INTRODUCTION}

Guava (Psidium guajava L.) is one of the most famous species of Myrtaceae family that is considered a fruit tree worldwide. More than usual, the guava fruits are consumed in their fresh state than they are processed to products such as jam, jelly, juice, and syrup (Murray and Campbell 1989). In addition to the purpose of the tree to produce edible fruits, the leaves of the guava tree reportedly constitute essential traditional medicinal properties for diarrhea (Nahdi et al. 2006). Originally, guava is from the American tropics (Nakasone and Paull 1998); although the tree is currently spread worldwide, irregardless of the ecological or climatic zones. The guava tree performance is reportedly higher in the tropical areas below 800-1000 m asl (Ecocrop 2015) than on low and high altitude land (up to $2000 \mathrm{~m}$ above sea level (asl) (Ecocrop 2015). In addition to the altitude conditions, the growth and productivity of the guava tree are also coupled by annual rainfall in the range of 1000-2000 mm per year (Nakasone and Paull 1998), sufficient sunlight for maximum photosynthesis, 70 to $90 \%$ relative humidity and 15 to $34^{\circ} \mathrm{C}$ ambient temperature (Technical Mission of the Republic of China 2011). The guava tree is adaptable to harsh environments such as drought, acidic soils, and tolerance to shading conditions (Ecocrop 2015). Amongst the wide range of guava varieties, 'kristal' guava is the prominent fruit in
Indonesia. The variety was introduced to Indonesia by the Taiwan Technical Mission, and it is mainly cultivated in Bogor (Kementerian Pertanian 2015). The cultivation of the variety has since spread over both, low and high altitude, orchard, and back yard.

'Kristal' guava fruit is highly preferred to other Indonesian fruits due to its delicious crunchy taste, seedless and nutritious content, i.e., rich in antioxidants, natural fiber, and vitamin C (Jiménez-Escrig et al. 2001; Susanto et al. 2019; Guntarti and Hutami 2019). These properties give 'kristal' guava high potential to substitute the imported subtropical fruits, such as, pears and apples. The estimated cost of importing fruits was predicted to be IDR 6.9 trillion in 2018, creating a big market opportunity for domestic guava farmers to improve guava production and penetrate into the local market to replace fruit imports (Kementerian Pertanian 2019).

In 2016, Indonesian guava production recorded 206985 tons, and a decline was recorded in 2018 with production of 200495 tons of fruits (BPS 2018). There is need to improve production of guava fruit in Indonesia so as to meet the increasing demand stemming from the increasing population growth and the increasing awareness of healthy lifestyles which is recommending daily consumption of fruits at a rate of $150 \mathrm{~g}$ per day (Pusdatin 2019).

Previous studies have reported improvement of guava production through the pruning approach (Susanto et al. 
2019) and strangulation approach (Widyastuti 2019). However, there are no studies in regard to the quality aspect of the fruits. Fruit quality is one of the key factors that influence consumer preference. Generally, Indonesians value the outward fruit appearance, i.e., fresh-look and spot-free, and the size, i.e., preferably bigger fruits to smaller ones. To produce high-quality fruits, monitoring of the production process has to begin from the field. In that context, the key factors that affect fruit quality include; cultural practice and the environmental condition. One of environmental elements that could affect fruit growth is land altitude. Land altitude influences plant microclimate such as temperature and relative humidity. Previous studies reported the difference of fruit quality as the effect of land altitude in figs (Trad et al. 2013), pineapple guava (ParraCoronado et al. 2018) and Columbian guava (Solarte et al. 2014). Therefore, this study aimed to evaluate the 'kristal' guava fruit quality in response to the different altitudes of growing location and cultural practice.

\section{MATERIALS AND METHODS}

\section{Study site}

This research was conducted in January-March 2019 in Bogor, West Java, Indonesia. A total of four treatments were used; i.e., fruits that originated from low altitude with an intensive cultural practice (LI), low altitude with less intensive cultural practice (LL), middle altitude with intensive cultural practice (MI), and middle altitude with less intensive cultural practice (ML). The detailed variance of cultural practices is shown in Table 1.

\section{Procedures}

The fruits that originated from low altitudes were harvested from a local farmer's orchard in Cikarawang village, Darmaga subdistrict (Bogor, Indonesia) with an altitude of about $200 \mathrm{~m}$ above sea level (asl). The fruits that originated from middle altitude were harvested from a local farmer's orchard in Sukajadi village, Tamansari subdistrict with an altitude for about $550 \mathrm{~m}$ asl. Fruits were collected from 5-years-old 'kristal' guava trees that exposed by treatment as showed in Table 1. All the treatments were arranged in a completed randomized design and each treatment had five trees as replicates. Each tree had five fruits observed as experimental units. Sampling was done by using the random method. Sampling in form of fruit picking was done during the same day in all locations.

Observed variables were the external and internal quality of the fruit. The variables of external fruit quality were fruit weight, diameter and fruit softness, whilst, the variables of internal fruit quality were total dissolved solids (TSS), titratable acid (TA), the ratio of TSS/TA and vitamin $\mathrm{C}$. The test of the aforementioned variables were conducted at the Postharvest Laboratory, Faculty of Agriculture, IPB University. To measure fruit softness (mm per $50 \mathrm{~g}$ per second), a penetrometer was used in three spots for every fruit, i.e., upper part, middle part, and lower part of the fruit. Total soluble solids (TSS) were measured by dropping juice of blended fruit on a lens of a hand refractometer (Brix). Titratable acid (TA) was measured by using $\mathrm{NaOH}$ titration method. Distilled water was added to a sample of $10 \mathrm{~mL}$ of guava juice to reach the final volume of $100 \mathrm{~mL}$. A portion of $10 \mathrm{~mL}$ of the solution was transferred to a new tube and three drops of phenolphthalein were added to the sample before titration. The sample was titrated with $0.1 \mathrm{~N} \mathrm{NaOH}$ until the solution color turned to pink. The vitamin $\mathrm{C}$ content was measured by iodine $0.01 \mathrm{~N}$ titration method. This method was the modification of the previous report (Suntornsuk et al. 2002). Approximately, $25 \mathrm{~g}$ of fruit was blended into a juice and $10 \mathrm{~mL}$ of the filtered juice was mixed with distilled water to reach the final volume of $100 \mathrm{~mL} .10 \mathrm{~mL}$ of fruit filtrate was transferred into $100 \mathrm{~mL}$ Erlenmeyer, and then it was combined with $2 \mathrm{~mL}$ of the starch indicator. The solution was titrated with $0.01 \mathrm{~N}$ iodine until the color turned to dark blue. The metabolites were profiled by using GCMS method (Agilent 7890 GC, 5975 mass selective detector). The sample for GCMS analysis was prepared in the form of methanol fruit extract of all fruit parts. The GCMS instrument produced a profile of metabolites that detected on the fruit extract.

\section{Data analysis}

All data, except the GCMS data, were pooled and analyzed using analysis of variance ( $\mathrm{F}$ test). Any significant differences between treatments were further tested by Duncan Multiple Range Test at $\alpha 5 \%$ (Mattjik and Sumertajaya 2013). For the GCMS results, data were processed by using $\mathrm{R}$ stat with a metabolomic package to form heatmap cluster gram.

Table 1. Description of 'kristal' guava cultural practices in different altitude

\begin{tabular}{|c|c|c|c|c|c|}
\hline \multirow{2}{*}{$\begin{array}{c}\text { Treatment } \\
\text { code }\end{array}$} & \multicolumn{5}{|c|}{ Cultural practices } \\
\hline & PR & WC & OF & $\mathbf{A F}$ & PC \\
\hline LI & $\begin{array}{l}3 \text { times per year } \\
\text { after harvest }\end{array}$ & Every month & $\begin{array}{c}40 \mathrm{~kg} ; \\
3 \text { times per year }\end{array}$ & 250 g NPK; 3 times per year & $\begin{array}{c}\text { Before FB; } \\
\text { IC + FC }\end{array}$ \\
\hline LL & No & Every 6 months & $\begin{array}{c}25 \mathrm{~kg} \\
1 \text { time per year }\end{array}$ & $200 \mathrm{~g}$ NPK, 1 time per year & $\begin{array}{l}\text { Before FB; } \\
\text { IC }\end{array}$ \\
\hline MI & $\begin{array}{l}3 \text { times per year } \\
\text { after harvest }\end{array}$ & Every month & $\begin{array}{c}40 \mathrm{~kg} \text {; } \\
3 \text { times per year }\end{array}$ & $250 \mathrm{~g}$ NPK, 3 times per year & $\begin{array}{c}\text { Before FB; } \\
\text { IC + FC }\end{array}$ \\
\hline ML & No & Every 6 months & $\begin{array}{c}30 \mathrm{~kg} ; \\
2 \text { times per year }\end{array}$ & 220 g NPK, 2 times per year & $\begin{array}{l}\text { Irregular; } \\
\text { IC }\end{array}$ \\
\hline
\end{tabular}

Notes: LI: low altitude-intensive cultural practice, LL: low altitude-less intensive cultural practice, MI: middle altitude-intensive cultural practice, ML: middle altitude-less intensive cultural practice, PR: pruning, WC: weed control, OF: organic fertilizer application (per tree), AF: anorganic fertilizer application (per tree), PC: pest control, FB: fruit bagging, IC= insecticide, FC: fungicide 


\section{RESULTS AND DISCUSSION}

The results of $\mathrm{F}$ test showed that variation of altitudes and cultural practices had effect on external fruit quality of 'kristal' guava (Figure 1). The external quality of guava fruits was determined by fruit weight, fruit diameter, and fruit softness. The recorded fruit weight was higher in intensive cultural practice, in both low and middle altitude, than in less intensive cultural practice (Figure 1A). In intensive cultural practice, fruit weight was increased by $26 \%$ in low altitude and $37 \%$ in middle altitude compared to the less intensive cultural practice. The high fruit weight recorded under intensive cultural practice, irregardless of altitude variation, was attributed to the big size and wide diameter of the fruits. The intensive cultural practice increased the fruit diameter by $10 \%$ in low altitude and $17 \%$ in middle altitude (Figure 1B).

The external appearance of 'kristal' guava fruit was slightly varied among locations. There was a tendency that the smoothest surface was showed by fruit from moderate altitude-intensive cultural practice, while the rough surface was depicted in fruit from moderate altitude-less intensive cultural practice (Figure 1C). In addition, there was a size improvement of fruit originated from intensive cultural practices compared to less intensive ones (Figure 2). The Indonesian population prefers bigger and larger fruits to smaller fruits. Hedonic test involved 50 untrained panelists revealed that the 'kristal' guava fruit bigger than $200 \mathrm{~g}$ was more favorable than the small size (Unpublished data). With regard to the preference of the consumers, the supermarkets are inclined to increase demand for large fruits. This norm encourages the market potential of large, big, and heavy guava fruits. Therefore, the best approach that should be used in guava production for business purposes is the intensive cultural practice.

In terms of fruit softness, middle altitude with less intensive cultural practices produced fruits with significantly lower levels of softness than fruits from similar practices in lower altitudes. In contrast, ParraCoronado et al. (2018) showed that the fruit from higher altitude had a higher fruit softness than lower altitude fruit. However, this finding was in agreement with previous study in figs that showed the softer fruit originated from low land compared to middle land (Trad et al. 2013). The variation of the fruit softness was as a result of differences in cell wall components. The decrease of components such as hemicellulose, cellulose, lignin, and pectin as the cell wall supporting components led to the soft texture of the fruits (Jain et al. 2003). In addition, fruit softness from middle altitudes also significantly lower than guava fruit from intensive culture in both low and middle altitudes. It was indicated that the presence of intensive culture could help farmers to produce more guava fruit in a similar quality of fruit softness either in low or middle land.
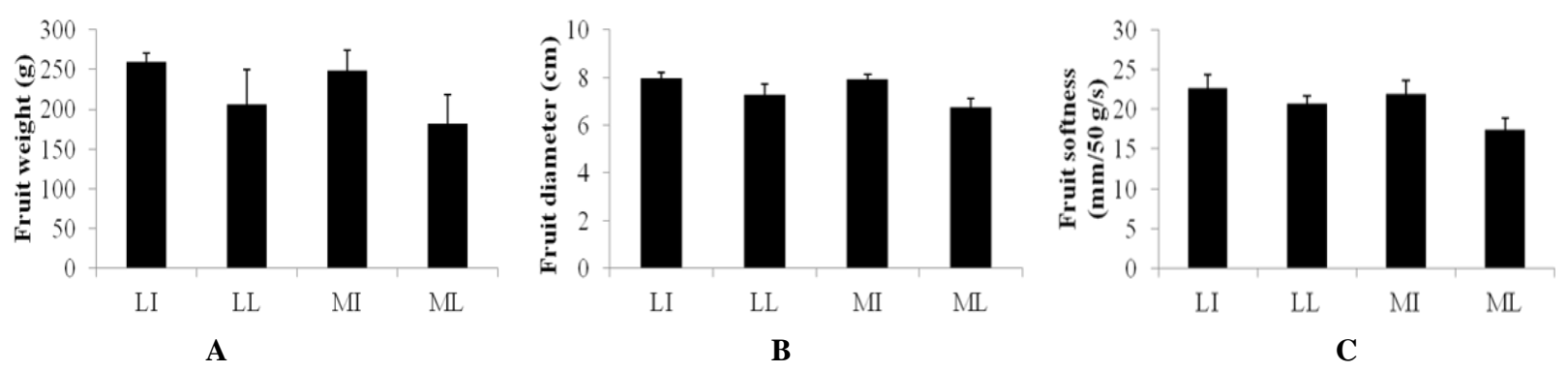

Figure 1. The external quality of 'kristal' guava fruit in terms of fruit weight (A), fruit diameter (B), and fruit softness (C) in response to different altitudes and cultural practices. Notes: $\mathrm{LI}=$ low altitude-intensive cultural practice, $\mathrm{LL}=$ low altitude-less intensive cultural practice, $\mathrm{MI}=$ middle altitude-intensive cultural practice, $\mathrm{ML}=$ middle altitude-less intensive cultural practice. The error bar on graph represents data variability.

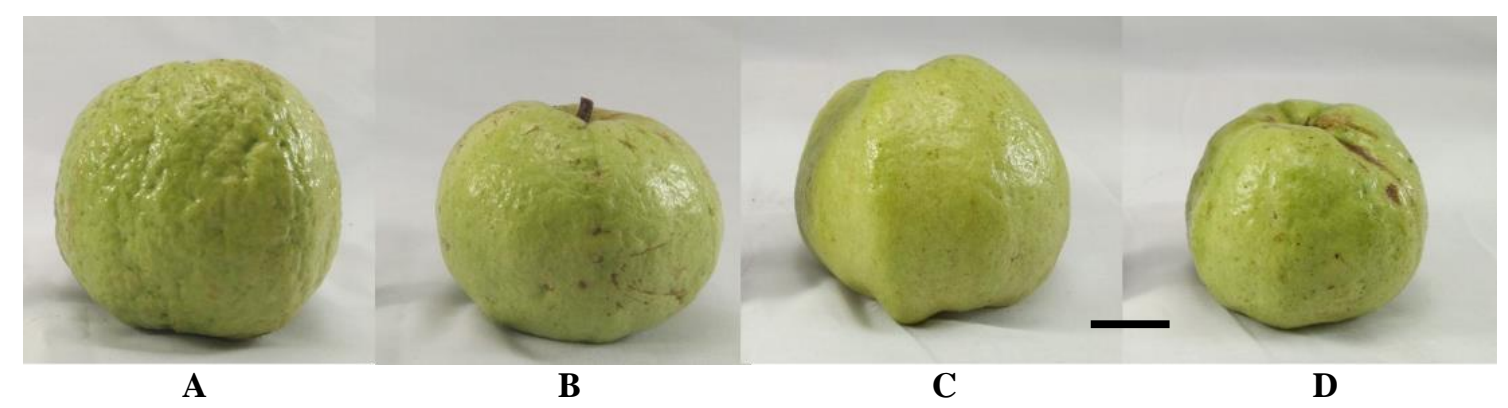

Figure 2. The external appearance of 'kristal' guava fruit in the term of response to different altitudes and cultural practices. Notes: A. $\mathrm{LI}=$ low altitude-intensive cultural practice, $\mathrm{B} . \mathrm{LL}=$ low altitude-less intensive cultural practice, $\mathrm{C}$. $\mathrm{MI}=$ middle altitude-intensive cultural practice, $\mathrm{D} . \mathrm{ML}=$ middle altitude-less intensive cultural practice. $\mathrm{Bar}=2 \mathrm{~cm}$ 
Another factor that could have affected the fruit softness is storage period. Standard storage period for guava fruit in room temperature is three days (Dhyan et al. 2014; Mahajan et al. 2009). After the fourth day, the fruit goes underweight reduction due to shrinkage, resulting in the soft fruit texture. Furthermore, the optimum temperature of guava fruit storage is $6^{\circ} \mathrm{C}$, and the optimum relative humidity is $90-95 \%$. The higher the storage temperature, the faster the fruits ripen and soften (Mahajan et al. 2009).

In addition to external quality, the current study also examined the internal quality of ' $k$ ristal' guava that varied among the treatments (Figure 3). A previous study reported the abundance of vitamin $\mathrm{C}$ in guava, even compared to the citrus, such as pummelo (Kalsum et al. 2015; Romalasari et al. 2017). Vitamin $C$ is an essential nutrient to maintain body health (Lee and Kader 2000). Thus, the content of vitamin $C$ in guava is crucial and it was evaluated in this study. In that context, the highest vitamin $\mathrm{C}$ content was recorded in fruits from middle altitude and intensive cultural practice, whilst the lowest vitamin $\mathrm{C}$ was recorded in fruits from low altitude. In simple terms, fruits cultivated in middle altitude tended to have higher vitamin $\mathrm{C}$ content than the fruits cultivated the low altitude. An average of $154.99 \mathrm{mg}$ per $100 \mathrm{~g}$ and $135.52 \mathrm{mg}$ per $100 \mathrm{~g}$ of vitamin $\mathrm{C}$ were recorded in fruits cultivated in middle altitude and low altitude, respectively (Figure 3a). Similar findings were reported in studies that were conducted in Bogor (200 $\mathrm{m}$ asl), Malang (700 m asl), Gunung Kidul (886 m asl) by (Guntarti and Hutami 2009), which showed that vitamin C content of the guava fruits increased as the altitude of the planting location increased. Intensive cultural practice could also result in an increase in the production of vitamin $\mathrm{C}$ on both low and middle altitudes. The average quantity of vitamin $C$ of guava fruits from intensive cultural practice was $153.53 \mathrm{mg}$ per $100 \mathrm{~g}$ whilst that from less intensive cultural practice was $136.99 \mathrm{mg}$ per $100 \mathrm{~g}$. The estimated increase of vitamin $\mathrm{C}$ production in intensive cultural practice was estimated at $6.42 \%$ in low altitude and $17.71 \%$ in middle altitude. However, vitamin $\mathrm{C}$ content was higher in intensive farming practices compared to less intensive farming (Figure 3A). Previous studies showed a specific range of vitamin $\mathrm{C}$ content on 'kristal' guava, i.e., 121.30$146.18 \mathrm{mg}$ per $100 \mathrm{~g}$ (Romalasari et al. 2017) and 95.72$177.08 \mathrm{mg}$ per $100 \mathrm{~g}$ (Mahendra et al. 2017). Fruit vitamin $\mathrm{C}$ was predominantly affected by its maturation stages and also geographical growth location (Gull et al. 2012).

The chemical quality of the guava fruit could be assessed based on total soluble solids (TSS) and titratable acid (TA) of the fruit juice (Susanto et al. 2019). The highest TSS was found in low altitude fruit with intensive cultural practices; however, it was not significantly different compared to the fruit from moderate altitude with or without intensive culture. The lowest TSS was found in the fruit from low altitude with less intensive cultural practices (Figure 3B). The lower TSS as the effect of the lower altitude was similar to previous study by ParraCoronado et al. (2018), however, it was in contrast to Solarte et al. (2014) finding. These differences might be associated with the presence of variation in terms of fruit ripening stage. As the ripening proceeded, there was a tendency to the increasing of TSS content in fruit (Hasimi et al. 2016).

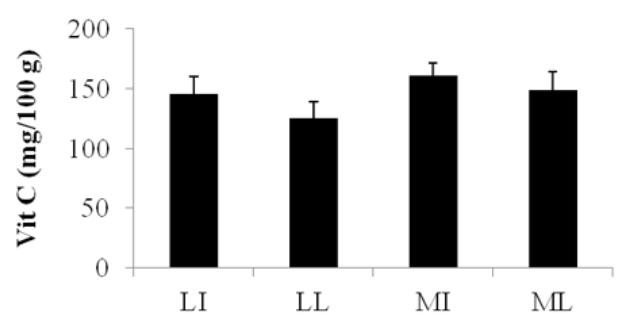

A

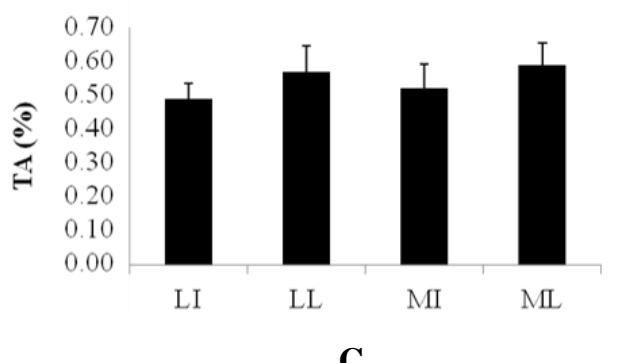

C

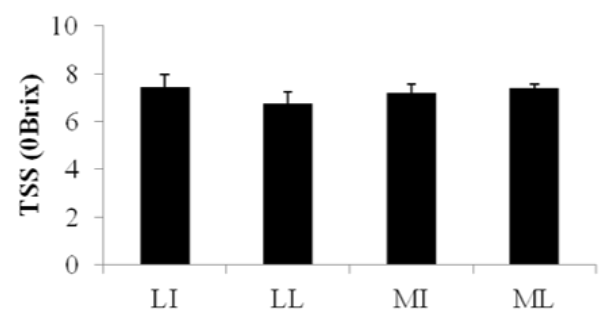

B

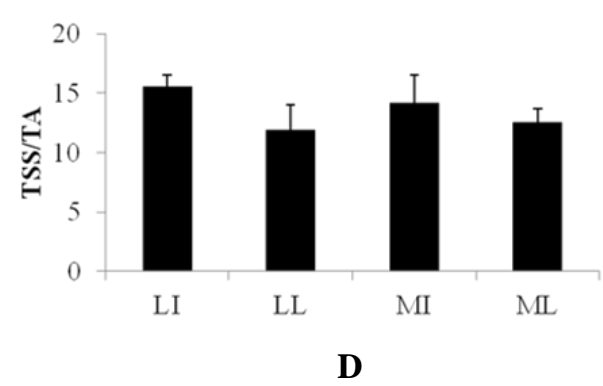

Figure 3. The internal quality of 'kristal' guava fruit in terms of vitamin C (A), total soluble solids/TSS (B), titratable acid/TA (C), and the ratio of TSS/TA (D) in response to different altitudes and cultural practices. Notes: $\mathrm{LI}=$ low altitude-intensive cultural practice, LL = low altitude-less intensive cultural practice, $\mathrm{MI}=$ middle altitude-intensive cultural practice, $\mathrm{ML}=$ middle altitude-less intensive cultural practice. The error bar on graph represents data variability 
In contrast, the lowest TSS content was observed at low altitudes with less intensive culture. The low TSS content can be attributed to the small quantity of inorganic fertilizer that was applied, i.e., $200 \mathrm{~g}$ NPK annually. The fruits from a tree that was supplied with optimum levels of potassium were sweeter than the fruits that were provided with less amount of potassium fertilizer. Potassium is one of the essential macronutrients that influence the production of sugar and consequently determined the sweetness of the fruits (Marschner 2012).

In terms of TA, the highest result was recorded in the fruits collected from middle altitude with less intensive cultural practices. On the other hand, the lowest TA content recorded in the fruits from intensive cultural practice at low altitudes. The application of intensive cultural practices reduced the guava fruit acidity with $16.33 \%$ and $13.46 \%$ compared to the less intensive cultural practice in low and middle altitudes, respectively (Figure 3C). This finding contributed to the previous studies that evaluate only the effect altitude variation, so that in some cases the TA showed greater in low altitude than high one (ParraCoronado et al. (2018), while other study reported the opposite result (Solarte et al. 2014).

Among the internal quality variables that were determined in the current study, there were TSS and TA which indicate the total sugar content in the fruit and the acid content in the fruit, respectively. The ratio between the two variables is essentially associated with the fruit taste, nutritional content, and also the level of consumer acceptance. As such, the current study evaluated the ratio between TSS and TA. The findings of the study showed that the highest ratio of TSS/TA was recorded in the fruits cultivated under intensive cultural practice in both low and middle altitudes (Figure 3D). This implies that the taste composition of the fruits cultivated under intensive cultural practices was sweeter and less acidic compared to the fruits cultivated under less intensive cultural practices, in either low or middle altitude. The Indonesian population prefers the latter fruits for they are sweeter and more tasteful compared to the former fruits which are highly acidic. As shown by previous studies, the content of TSS and TA were not significantly influenced by pre-harvest treatment such as pruning (Susanto et al. 2019; Lakpathi et al. 2013). On the other hand, the level of fruit maturity predominantly influenced these two variables. The TSS increased whilst TA decreased, as the process of fruit ripening preceded (Dolkar et al. 2017).

The GCMS metabolite profile showed a clear difference between fruit from middle and low altitude growth locations (Figure 4). Fruits harvested from low altitude contained more metabolites than fruits harvested from middle altitude, i.e., 17 and 14 metabolites, respectively. A total of six metabolites were detected in fruits harvested from both low and middle altitudes, i.e., hydroxymethylfurfural, furfural, $\gamma$-sitosterol, hexadecanoic acid, 9,12-octadecadienoic and 4h-pyran-4-one, 2,3dihydro-3,5-dihydroxy-6-methyl. Hydroxymethylfurfural became the most dominant metabolite detected in both samples. Compared to middle altitude fruit, low altitude fruit contained several health-useful metabolites, such as vitamin $\mathrm{E}(1.13 \%)$ and caryophyllene $(3.79 \%)$. Vitamin E or $\alpha$-tocopherol $\left(\mathrm{C}_{29} \mathrm{H}_{50} \mathrm{O}_{2}\right)$ was a beneficial and essential vitamin for human health due to its strong antioxidant activities against various free radicals (Burton and Traber 1990). Additionally, caryophyllene was one of the sesquiterpenes with strong antioxidant activities (Calleja et al. 2013). Thus, this finding provided preliminary information that fruit from low altitude contained more beneficial metabolites than those from middle altitudes.

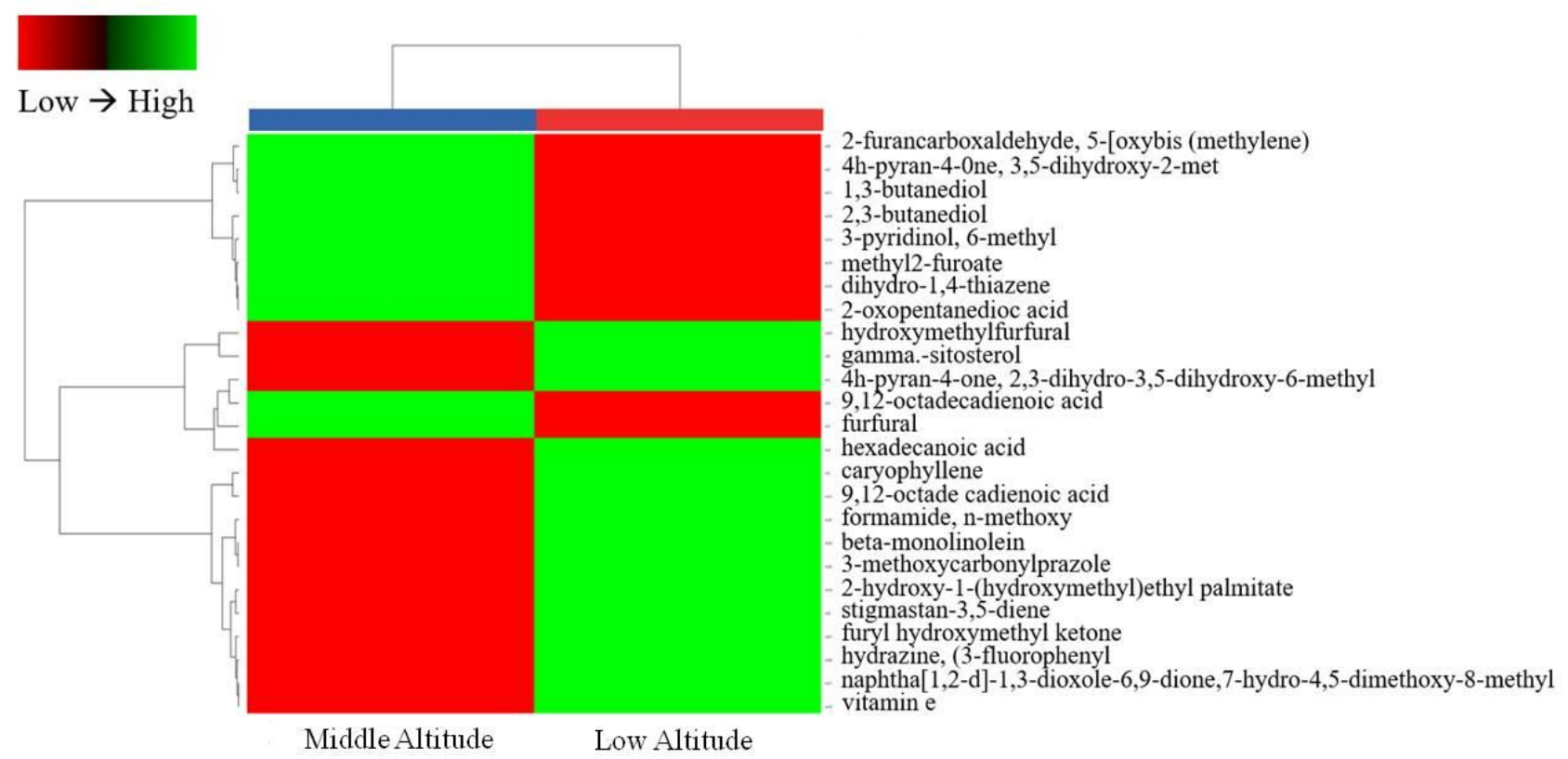

Figure 4. The heatmap cluster gram showed various metabolites detected by using GCMS method on guava fruit from low and middle altitude 
Previous studies reported results that are similar to the observations of the current study, in regard to the influence of altitude on fruit size. The fruits from low altitudes also showed better quality in terms of fruit size. Guava plants had a broad growing zone, ranging from lowlands to highlands with an altitude of $1500 \mathrm{~m}$ above sea level (Ashari 2006). In contrast, this study finding indicated the better quality (larger size and heavier) of guava fruit harvested from low altitude rather than middle altitude, regardless of the type of cultural practices adopted. It was relatively similar to the previous study by (Widyastuti 2019) who reported that 'kristal' guava plant productivity in Lampung (24 m asl) and Bogor (197 m asl) was almost the same for about $12.4 \mathrm{~kg}$ per tree and $12.5 \mathrm{~kg}$ per tree. Guava productivity in Sukabumi (956 m asl) was only 10.8 $\mathrm{kg}$ per tree. It could be the indicators that guava plant is better to plant in low altitude rather than middle ones.

Intensive cultural practices yielded to an improvement of fruit quality which was indicated by an increase in fruit weight and fruit diameter. The higher dosage of organic fertilizer in guava orchard with intensive cultural practice compared to those with less intensive practice could be associated with better fruit quality produced. The dosage of organic fertilizer was $120 \mathrm{~kg}$ per year in an orchard with intensive cultural practice while it was only $25-60 \mathrm{~kg}$ per year in an orchard with less intensive cultural practice. Previous studies reported the improvement of guava fruit quality due to the application of organic fertilizers (Ram et al. 2007; Das et al. 2015). Besides, there was a positive correlation between the macronutrients and micronutrients in the available soil (Shukla et al. 2014).

Furthermore, the guava tree with less intensive cultural practice was not exposed to pruning treatment (Table 1). Pruning was a plant growth regulation technique that can improve the farmers' accessibility to do maintenance, such as fertilizing, pesticide spraying, and harvesting (Krajewski and Krajewski 2011; Gilman and Black 2011). The intensity of sunlight received by pruned plants was higher than unpruned one so that it could stimulate the growth of new productive shoots (Willaume et al. 2004) and ultimately could increase fruit production and quality (Prastowo et al. 2015). Canopy pruning could also shorten the distance between the source and sink so that photosynthate translocation becomes faster, smoother, and more efficient (Suyanto and Irianti 2011). Optimal flowering and fruit enlargement could run if supported by adequate photosynthate. The findings of the current study were similar to results of previous research, which reported a decrease in fruit weight and diameter in unpruned plants (less intensive cultural). A study by Basu et al. (2007) showed that unpruned trees produced fewer shoots, lower crop production, and subsequently lower fruit weights than fruit from pruned trees. The best pruning technique for 'kristal' guava plants was previously reported by Susanto et al. (2019) who recommended leaving only four pairs of leaves. This pruning practice led to better performance of the guava plants than leaving eight pairs of leaves and without pruning. Pruning by leaving four pairs of leaves produced 102.3 flowers, pruning by leaving eight pairs of leaves produced 86.6 flowers, while without pruning produced 52.2 flowers (Susanto et al. 2019). Besides, pruning removed the diseased leaves, dead leaves and branches, water sprouts, and overlaying leaves inside the tight canopy (Gilman and Black 2011).

In conclusion, the fruit quality of 'kristal' guava significantly varied with differences in altitude and cultural practices. The fruits that were harvested from low altitudes were significantly bigger and heavier than the fruits harvested from middle altitudes. In terms of fruit softness, the fruits from middle altitudes were crispier than fruits from other altitudes. The fruit chemical qualities, indicated by TSS/TA ratio and vitamin $\mathrm{C}$, were better in guava orchard under intensive cultural practice than the guava orchard under less intensive cultural practice. The intensive cultural practice also improved the guava fruit size compared to the less intensive cultural practice. This finding may be attributed to pruning which is performed in intensive cultural practice. More beneficial metabolites for human health such as vitamin E and caryophyllene were found in fruit from low altitude.

\section{ACKNOWLEDGEMENTS}

This research was funded by Directorate of Research and Community Service, Directorate General of Research and Development Strengthening, Ministry of Research, Technology and Higher Education, the Republic of Indonesia for providing financial support through a research contract for the fiscal year 2019 no. 3/E1/KP.PTNBH/2019 on March 29 $9^{\text {th }}, 2019$.

\section{REFERENCES}

Ashari S. 2006. Principle of Horticulture 2nd ed. Butterworth Heinemann, London, UK.

BPS. 2018. Statistik Tanaman Buah-buahan dan Sayuran Tahunan Indonesia 2017. Subdirektorat Statistik Hortikultura BPS, Jakarta. [Indonesian]

Basu J, Das B, Sarkar S, Mandal KK, Banik BC, Kundu S, Hasan MA, Jha S, Ray SK. 2007. Studies on the response of pruning for rejuvenation of old guava orchard. In: Singh G, Chandra R, Kishun R (eds). Proc. Ist IS on Guava Acta Hort 35: 303-309.

Burton GW, Traber MG. 1990. Vitamin E: Antioxidant activity, biokinetics, and bioavailability. Ann Rev Nutr 10: 357-382. DOI: 10.1146/annurev.nu.10.070190.002041

Calleja MA, Vieites JM, Montero-Meterdez T, Torres MI, Faus MJ, Gil A, Suarez A. 2013. The antioxidant effect of b-caryophyllene protects rat liver from carbon tetrachloride-induced fibrosis by inhibiting hepatic stellate cell activation. Br J Nutr 109: 394-401. DOI: 10.1017/S0007114512001298.

Das K, Roy D, Sengupta D, Datta P. 2015. Organic fruit production of guava cv.L-49 in Gangetic alluvial plain of West Bengal. The Bioscan 10: 1371-1374.

Dhyan CS, Sumarlan SH, Susilo B. 2014. The influence of bee wax coating and storage temperature on guava's quality (Psidium guajava L.). Jurnal Bioproses Komoditas Tropis 2: 1-4

Dolkar D, Bakshi P, Gupta M, Wali VK, Kumar R, Hazarika TK, Kher D. 2017. Biochemical changes in guava (Psidium guajava) fruits during different stages of ripening. Indian J Agri Sci 87: 257-260.

Ecocrop. 2015. Ecocrop Database. FAO, Rome, Italy.

Gilman EF, Black RJ. 2011. Pruning Landscape Trees and Shrubs. University of Florida, Florida, USA. 
Gull J, Sulfana B, Anwar F, Naseer R, Ashraf M, Ashrafuzzaman M. 2012 Variation in antioxidant at three ripening stages of guava (Psidium guajava L.) fruit from different geographical regions of Pakistan. Molecules 17: 3165-3180. DOI: 10.3390/molecules17033165.

Guntarti A, Hutami EN. 2019. Validation and vitamin C testing in crystal guava (Psidium guajava L.) with variations of origin with the HPLC method. Int J Chem 11: 52-29. DOI: 10.5539/ijc.v11n1p52

Hasimi NR, Poerwanto R, Suketi K. 2016. Degreening siam tangerine fruit (Citrus nobilis) in ethylene concentrations and exposure durations. J Hort Indo 7: 111-120.

Jain N, Dhawan K, Malhotra S, Singh R. 2003. Biochemistry of fruit ripening of guava (Psidium guajava L.): Compositional and enzymatic changes. Plant Foods Hum Nutr 58: 309-315. DOI: 10.1023/B:QUAL.0000040285.50062.4b

Jiménez-Escrig A, Rincón M, Pulido R, Saura-Calixto F. 2001. Guava fruit (Psidium guajava L.) as a new source of antioxidant dietary fiber. J Agric Food Chem 49: 5489-5493. DOI: 10.1021/jf010147p.

Kalsum U, Susanto S, Junaedi A. 2015. Quality improvement of pummelo (Citrus maxima (Burm.) Merr.) using leaf-to-fruit ratio arrangement and fruit bagging. Am J Plant Physiol 10: 68-76. DOI: 10.3923/ajpp.2015.68.76

Kementerian Pertanian. 2015. Buku Lapang Jambu 'Kristal'. Direktorat Jenderal Hortikultura, Jakarta, Indonesia.

Kementerian Pertanian. 2019. Prospek usaha jambu kristal menggiurkan. Available online: http://hortikultura.pertanian.go.id/?P=3244 (Accessed on 12 May 2019). [Indonesia].

Krajewski AJ, Krajewski SA. 2011. Canopy management of sweet orange, grapefruit, lemon, lime and mandarin trees in the tropics: Principles, practices and commercial experiences. In: Benkeblia N (eds). Proc. 1st IS on Trop Hort Acta Hort 65-76.

Lakpathi G, Rajkumar M, Chandrasekhar R. 2013. Effect of pruning intensities and fruit load on growth, yield and quality of guava [Psidium guajava (L.)] cv. Allahabad safeda under high-density planting. Int J Curr Res 5: 4083-4090. DOI:

Lee SK, Kader AA. 2000. Preharvest and postharvest factors influencing vitamin C content of horticultural crops. Postharvest Biol Technol 20: 207-220. DOI: 10.1016/S0925-5214(00)00133-2

Mahajan BVC, Sharma SR, Dhall RK. 2009. Optimization of storage temperature for maintaining quality of guava. J Food Sci Technol 46: 604-605.

Mahendra IG, Rai IN, Wiraatmaja W. 2017. Efforts to increase production and quality of "Kristal" guava variety (Psidium guajava L. cv. Kristal) by fertilization. Agrotrop 7: 60-68.

Marschner P. 2012. Marschner's Mineral Nutrition of Higher Plants. 3rd ed. Elsevier, New York.

Mattjik AA, Sumertajaya IM. 2013. Perancangan Percobaan dengan Aplikasi SAS dan Minitab. IPB Press, Bogor. [Indonesian]

Murray MJ, Campbell CA. 1989. Guava and passionfruit as commercial crops in Florida. Proc Fla State Hort Soc 102: 212-213.

Nahdi MS, Martiwi INA, Arsyah DC. 2006. The ethnobotany of medicinal plants in supporting the family health in Turgo, Yogyakarta, Indonesia. Biodiversitas 17 (2): 900-906. DOI: 10.13057/biodiv/d170268
Nakasone HY, Paull RE. 1998. Tropical fruits. CAB International. Oxford, UK.

Parra-Coronado A, Fischer G, Camacho-Tamayo J. 2018. Post-harvest quality of pineapple guava [Acca sellowiana (O. Berg) Burret] fruits produced in two locations at different altitudes in Cundinamarca, Colombia. Agronomía Colombiana 36: 68-78. DOI: 10.15446/agron.colomb.v36n1.68577

Prastowo NH, Roshetko JM, Manurung G, Nugraha E, Tukan J, Harum F. 2015. Tehnik Pembibitan dan Perbanyakan Vegetatif Tanaman Buah. World Agroforestry Centre (ICRAF) \& Winrock International.

Pusdatin. 2019. Konsumsi Makanan Penduduk Indonesia. Available online: http://www.pusdatin.kemkes.go.id/ download.php (accessed on 12 May 2019). [Indonesian]

Ram RA, Bhriguvanshi SR, Pathak RK. 2007. Integrated plant nutrient management in guava (Psidium guajava L.) cv. Sardar. Acta Hort 735: 345-350. DOI: 10.17660/ActaHortic.2007.735.49

Romalasari A, Susanto S, Melati M, Junaedi A. 2017. Improvement fruit quality of guava (Psidium guajava L.) cv. crystal by different colors and bagging materials. J Hort Indo 8: 155-161.

Shukla SK, Adak T, Singha A, Kumar K, Singh VK, Singh A. 2014. Response of guava trees (Psidium guajava) to soil applications of mineral and organic fertilisers and biofertilisers under conditions of low fertile soil. J Hort Res 22: 105-114. DOI: 10.2478/johr-20140027

Solarte ME, Melgarejo LM, Martínez O, Hernández MS, FernándezTrujillo JP. 2014. Fruit quality during ripening of Colombian guava (Psidium guajava L.) grown at different altitudes. J Food, Agric Env 12: 669-675.

Suntornsuk L, Gritsanapun W, Nilkamhank S, Anocha P. 2002. Quantitation of vitamin C content in herbal juice using direct titration. J Pharm Biomed Anal 28: 849-855. DOI: 10.1016/s07317085(01)00661-6.

Susanto S, Melati M, Aziz SA. 2019. Pruning to improve flowering and fruiting of 'Crystal' guava. AGRIVITA J Agri Sci 41: 48-54.

Suyanto A, Irianti TP. 2011. Studi hubungan karakteristik tipologi lahan yang digunakan terhadap kualitas hasil jeruk siem (Citrus nobilis var. Microcarpa) di Kabupaten Sambas. J Tek. Perkebunan dan PSDL 1: 42-48. [Indonesian]

Technical Mission of the Republic of China. 2011. Taiwan Guava Production Manual, 1st ed. Horticulture Crop Training and Demonstration Center, Ministry of Agriculture and Fisheries, Taipei, Taiwan.

Trad M, Gaaliche B, Renard CMGC, Mars, M. 2013. Inter- and intra-tree variability in quality of figs. Influence of altitude, leaf area and fruit position in the canopy. Sci Hort 162: 49-54. DOI: 10.1016/j.scienta.2013.07.032

Widyastuti RAD. 2019. Pengaturan dan peningkatan pembungaan untuk produksi buah jambu biji (Psidium guajava L.) 'kristal' di luar musim. [Dissertation]. Institut Pertanian Bogor, Bogor, Indonesia.

Willaume M, Lauri PE, Sinoquet H. 2004. Light interception in apple trees influenced by canopy architecture manipulation. Trees 18: 705713. DOI: $10.1007 / \mathrm{s} 00468-004-0357-4$. 